\title{
THE PREDATORY BEHAVIOR OF TWO WASPS, AGENOIDEUS HUMILIS (POMPILIDAE) AND SCELIPHRON CAEMENTARIUM (SPHECIDAE), ON THE ORB WEAVING SPIDER ARANEUS CORNUTUS (ARANEIDAE) ${ }^{1}$
}

\author{
By William Eberhard ${ }^{2}$ \\ Museum of Comparative Zoology, Harvard University
}

The nesting habits of many wasps have been studied, but much less is known of how they locate and capture their prey. Many wasps in the families Pompilidae and Sphecidae prey on orb weaving spiders, and knowledge of their predatory behavior is crucial to an understanding of the biology of orb weavers. This paper describes the hunting behavior of two species of wasp, Agenoideus humilis (Pompilidae) and the mud dauber Sceliphron caementarium (Sphecidae) which were observed preying on the orb weaver Araneus cornutus during July and August, 1968, and discusses the significance of their behavior for the spiders.

There was a dense population of the spider Araneus cornutus on the windows and shingled walls of a cottage on Lincoln Pond in the Huyck Preserve, Rensselaerville, New York. Spiders spun orbs in the early evening and sat at the hubs during the night, then (except for a few younger individuals) left the orbs and crouched in retreats during the day. The retreats were usually approximately tubular, silk-lined, and often had silk just beyond the mouth. Although most of the retreats around the cottage were in cracks beneath shingles, the spiders were especially plentiful around windows from which lights showed at night, and there were a number of retreats at the edges of window panes (there were $1530 \times 15 \mathrm{~cm}$ panes/window) and in the corners of window frames. Retreats like these, which

\footnotetext{
${ }^{1}$ This is part of a thesis done under the direction of Dr. H. W. Levi and submitted to the Department of Biology of Harvard University, in partial fulfillment of requirements for the $\mathrm{PhD}$ degree. The work was done in 1968 while I held a Summer Fellowship from the E. N. Huyck Preserve, Inc.; I thank the directors and staff of the Preserve for making it possible for me to do this work in such pleasant surroundings. I thank Dr. H. E. Evans for encouragement and for identifying the wasps, and Mary Jane Eberhard, Robert Jeanne, and William Shear for helpful comments on the manuscript. Specimens of the species observed are deposited in the Museum of Comparative Zoology, Cambridge, Mass.

${ }^{2}$ Present address: Depto. Biologia, Universidad del Valle, Cali, Colombia.
} 
were not hidden from view, were made of silk, often approximately tubular, and usually open at both ends. The dark-colored spiders contrasted with the white woodwork as they rested in these retreats, and were thus easy to locate visually. Spiders in the field were usually impossible to see because their retreats were generally in curled leaves or under flakes of bark.

When sufficiently disturbed during the day, the spiders dropped out of their retreats. Sometimes they stopped before they reached the ground, hung motionless at the end of their trail lines for a short while, then climbed back to their retreats; other times they descended to the ground. Although they often began to crawl as soon as they landed on a flat surface, they usually remained motionless with their legs pulled tight against their bodies when they landed on irregular surfaces such as grass or leaf litter.

\section{Predatory behavior of Agenoideus humilis}

Agenoideus humilis is relatively rare in the northeastern U.S. (Evans and Yoshimoto I962) but was not hard to find around the cottage on Lincoln Pond, and has previously been collected there by both Kenneth Cooper in 1952 and Robert Matthews in 1967 (unpublished reports to the Trustees of the E. N. Huyck Preserve, Inc.). Evans and Yoshimoto summarize the literature on the biology of this species, noting that it is often found near buildings. It has been recorded preying on orb weavers in the araneid genera Neoscona, Araneus, and Conepeira, but there are no records of its predatory behavior.

Females of $A$. humilis were observed hunting for spiders on the walls and windows of the cottage. Typically, a wasp walked along the surface of the wall until she encountered a crack between two shingles, then walked up the crack and under the overlapping shingle, often staying out of sight for 30 seconds or more. The wasps did not investigate every crack they encountered, and often passed two or three before walking up one. They usually showed no obvious reaction when they encountered silk in them. Occasionally a wasp bent her abdomen forward beneath her so that the tip was near her head as she entered a crack.

Four complete wasp-spider encounters were observed. One involved a spider resting in a horizontal retreat at the top edge of a window pane. The wasp, after passing within two $\mathrm{cm}$ of another spider in a retreat, encountered some silk about two $\mathrm{cm}$ below the retreat and climbed directly to it. She touched the side of the 
retreat, climbed around to one end, curled her abdomen forward under herself, and moved in. Almost immediately the spider fell backwards out the other end, descended to the floor (these observations were made on a porch), and began to crawl away. The wasp flew out of sight for about 30 seconds (perhaps disturbed by my presence, see below), then came back ( $\mathrm{I}$ assume it was the same wasp), flew to the spot directly below the retreat where the spider had landed, and ran around quickly in that area. I could not discern any pattern in the search except that the wasp quickly began searching farther and farther from the original area. By the time the wasp had returned, the spider was about $0.5 \mathrm{~m}$ away and climbing along the wall under the edge of the second row of shingles. The area of the wasp's hunt quickly expanded to include the wall, and after about I 5 seconds she moved straight toward the spider which was about I $\mathrm{m}$ away now. She grabbed the spider with her legs and stung it once on the ventral side of its cephalothorax as soon as she reached it. The spider showed no defense against the wasp's attack. It stopped moving as soon as it was stung, and the wasp grabbed it near the base of one leg with her mandibles and began drawing it up the wall.

Wasps with spiders always moved backwards, dragging the spider behind them, and several wasps showed strong tendencies to drag their spiders upward. This behavior was probably preparation for a flight with the spider. One wasp was observed flying with a spider, and judging from the angle of its flight as it came to earth, it must have climbed at least $10 \mathrm{~m}$ up a tree that was $15-20 \mathrm{~m}$ from the site where it landed.

Each wasp dragging a spider paused periodically, released her grip on the spider and flew around for a short while, then returned and dragged the spider onward. When I moved the spider a short distance while a wasp was gone on one of these short excusions, the wasp returned to the spot where she had left the spider and ran around quickly (again I could see no pattern) in that area. When she reencountered the spider she stung it on the ventral side of its cephalothorax. This experiment was repeated several times, and even though the wasp encountered the spider from a different direction each time, she always stung it in the same region. The stinging was evidently released by the change in the spider's position, since wasps did not sting spiders which had not been moved. This behavior may normally occur when a wasp fails to completely paralyze a spider with her first sting. 
Two wasps were observed attacking spiders which had evidently been driven from their retreats and were hanging at the ends of threads. Each wasp flew close to (and probably hit) the spider, then immediately flew to the floor directly beneath the spider and ran around quickly. In both cases this first encounter caused the spider to descend only part of the way to the floor, and after a short time the wasp flew back up and buzzed the spider again. The quickness with which these wasps searched the floor below following their encounters with spiders suggests the wasps in the case reported above may have been disturbed.

One wasp's encounter with an $A$. cornutus exuvium was also observed. The skin hung near one entrance of an empty retreat, and when she encountered it the wasp inserted her sting into it two or three times.

Two spiders escaped after a wasp encountered them. There was a strong ( $>15 \mathrm{kmph}$ ) wind blowing when one of them left its retreat and hung on a thread as a wasp entered. The wasp flew down to the spider, but as the spider let out more thread, a gust of wind blew it arund the corner of the house. The wasp did not follow it, but landed on the wall. Another spider was at the mouth of its. retreat in the crack between two shingles as a wasp approached, and dropped out just as the wasp walked up the crack. The wasp walked on under the overlapping shingle, stayed out of sight for about 15 seconds, then walked on. After about a minute, the spider climbed back up its thread to its retreat.

In summary, spiders were always attacked while they were on surfaces, and those not on surfaces (on a thread) were driven to them and then attacked. The wasps used their superior speed and an ability to locate the ventral surface of the spider's cephalothorax to sting the spiders into paralysis. The wasps probably did not use vision to locate spiders in their retreats, but probably did use it to locate spiders which had fallen from their retreats and perhaps to locate the general area in which to search for retreats. Tactile or perhaps chemical stimuli from the skin of a spider released stinging behavior.

These observations of the predatory behavior of $A$. humilis differ dramatically from the description of the predatory behavior of $A$. sericeus (= Pompilus sericeus) by Soyer (1950). He saw these wasps hunting the orb weavers Araneus diadematus and $Z$ ygiella $x$-notata, but claimed that the wasps, by flying about until they fell into an orb and then searching sites to which the web threads led, used the spider's web to find its retreat. The observations above 
indicate that $A$. humilis did not use cues from the orb to locate the spiders. Although these differences may be due to differences in the species, it seems more likely that Soyer misinterpreted some of the behavior he observed.

\section{Predatory behavior of Sceliphron caementarium}

Sceliphron caementarium is much larger than $A$. humilis (length about $25 \mathrm{~mm}$ vs. about $8 \mathrm{~mm}$ ). This species has been recorded stocking its tubular mud cells with spiders in the families Araneidae, Thomisidae, Salticidae, Oxyopidae, Anyphaenidae, Clubionidae, Mimetidae, Theridiidae, and Lycosidae (Muma and Jeffers I945). In general, they take spiders commonly found on plants (Rau I935, Muma and Jeffers r945).

Two individuals of $S$. caementarium were observed searching for $A$. cornutus on and near the windows of the cottage, and 18 waspspider encounters were seen. $S$. caementarium appeared to use different signals than those used by $A$. humilis to locate spiders. The wasps hovered near the windows, alighting occasionally and sometimes walking across a pane or two, then flying on. They apparently oriented visually before landing since they almost always lit either on small dark spots which contrasted with their background (the white trim of the cottage) or in corners of window panes. Occasionally they lit on dark objects (usually masses of dead ephemeropterans) suspended by spider threads. The contrast between a spot and its background appeared to be more important in determining its attractiveness to a wasp than its shape, as the wasps often landed on dark spots bearing little resemblance to a spider crouching in its retreat. These wasps encountered only the spiders which were resting on the white woodwork of the house.

There were $A$. cornutus orbs on and near the windows, and the wasps sometimes flew into them as they hunted, but the wasps were strong and heavy enough that they quickly freed themselves. Their hunting behavior was never noticeably altered by such an encounter, indicating that they do not use the presence of an orb as a cue signalling the presence of a spider.

Memory of previous captures probably influenced the choice of a site for hunting: after depositing a spider in her nest (about $5 \mathrm{~m}$ away), one wasp resumed hunting at the same edge of the same window pane where that spider had just been captured. The intensity of hunting activities at a given site also may be influenced by previous experience at that site. Two windows which were examined only 
cursorily or not at all during intermittent searches for weeks prior were searched very thoroughly on one day when at least three spiders were captured there. About two weeks later, hunting intensity had returned to the level previous to the burst of captures.

The wasps may also establish hunting routes. One individual visited a series of four windows in the same order four times, each time after depositing a new spider in her nest. She caught all the spiders on the third and fourth windows, and the later visits to the first two windows were very brief.

When a wasp encountered a silken retreat with a spider in it she immediately pulled and tore at the silk in the side of the retreat with her mandibles. After a few tugs by the wasp, the spider usually left the retreat at the end farthest from the wasp and descended on a thread. Spiders usually remained inside vertical retreats longer when the wasp was attacking from below, leaving the top end hesitantly. One spider moved to the bottom of the retreat where a wasp was pulling, moved back up to the top end, and, when the wasp moved to the top along with it, dropped out the bottom.

The wasps pursued the spiders as they struggled out of their retreats and as they fell. Several times a wasp captured a spider just as it fell from the retreat and stung it as she flew away. On three occasions the spider fell to a windowsill and the wasp attacked it there. In each case the wasp grasped the spider with her mandibles and front pair of legs and curled her abdomen forward beneath her body and stung it. On one occasion a wasp stung a spider four times, the last three times on the ventral side of its cephalothorax. Several other times a wasp stung a spider as she flew, then landed and stung it at least once more.

On two occasions a spider dropped out of its retreat and hung on a line some distance below (once after it hit the windowsill and crawled off that). In one of these cases, the wasp captured the spider as it hung, and bent her abdomen forward and stung it as she flew away. In the second case, she landed on the windowsill after seizing the spider and bent her abdomen forward and sideways to sting it.

Usually a wasp paused for several seconds after stinging a spider, and on at least four occasions, the wasp's mouth was pressed against the mouth region of the spider during this pause. On one occasion the spider was rotated so that its mouth region was next to that of the wasp. The wasps may have been ingesting fluids from their victims' mouths during these pauses. 
Twice a wasp captured and then discarded a very small spider. Both spiders, which were less than half the size of the wasp's head, were captured at the bottoms of their retreats, stung in midair, then dropped as the wasp resumed hunting. There were a number of individuals of $A$. cornutus on the windows where the wasps hunted which were too large (i.e. larger in diameter than the wasp's mud cell), but no encounters with these individuals were observed. Sometimes the wasps appeared to avoid their retreats.

Occasionally hunting wasps paused and flattened themselves on a flat, light-colored surface in the sunlight. These pauses probably functioned to elevate the wasp's body temperature. The predominantly black coloration of $S$. caementarium (and $A$. humilis) may function to speed this process, but this is not certain since many wasps which do not obviously need to collect heat are also black.

Wasps attempted to sting three different empty spider skins which hung near empty retreats. Thus the stinging behavior of $S$. caementarium is probably released by the stimuli of contact with the surface of the spider, just as it is in A. humilis. This response would be highly adaptive for both wasps when they hunt for spiders which are difficult to see after they drop into litter below the retreat and assume cryptic postures. Apparently contact with arthropod cuticle of all kinds will not release stinging; once a $S$. caementarium landed on a phalangid (daddy-long-legs), but immediately flew on; the phalangid remained motionless.

The wasps did not capture all spiders they encountered. Twice a wasp failed to react when a spider fell from the retreat she was tearing at. Another relatively small spider was blown some distance as it descended on a thread, and the wasp did not follow it. Two other times, a spider did not leave when a wasp pulled at its retreat, and after several tugs, the wasp moved on. Both of these retreats were exceptional. One was under a large mass of dead ephemeropterans and spider silk and the wasp pulled at this mass rather than the retreat. The wall of the other was unusually strong because it was quite thick and made of thick fibers spun by a relatively large spider.

The observations above are not in complete agreement with published observations of $S$. caementarium predatory behavior. The Peckhams (1905) also saw this species (= Pelopaeus caementarium) hunting Araneus cornutus ( $=$ Epeira strix) on the side of a house, but recorded that the wasps walked along the wall and pried into nooks and crannies rather than hovering nearby and landing on dark 
spots. They also recorded that the wasps only seldom followed spiders which fell from their retreats. These differences may be due to differences in cues learned by individual wasps.

\section{Discussion}

The hunting behaviors reported above illustrate selective pressures on $A$. cornutus and other orb weavers. A spider at the hub of an orb in the daylight is probably relatively safe from attacks by predators not strong and heavy enough to escape easily from its web, but it is very vulnerable to attacks by large, visually orienting, versatile predators such as $\mathcal{S}$. caementarium. On the other hand, many insects fly only during the day, and it is certainly advantageous for the spider to use its web during the day. Devices such as stabilimenta found in webs of Cyclosa, Argiope, Uloborus, and others (Gertsch 1949) which obscure the spider's outline, a "stopping mesh" next to the orbs of Nephila, Metepeira, Argiope, Araneus, and others (McCook I 889), and signal threads leading to the web from the hiding place of Zygiella, Hyptiotes, Araneus, and others (McCook I889) may all function to hinder attacks by relatively large predators while allowing the spider to capture prey caught in the web during the day.

A spider off its web is relatively safe from larger predators because it can crawl into places too small for them, and also relatively safe from smaller substrate-bound predators because it can escape by falling and hanging on a thread. A spider in a retreat is probably only especially susceptible to wasps which are relatively good fliers, which are about its own size, which hunt by crawling into tight spots, and whose behavior can cope with the spider's escape behavior. A. larger wasp can attack an orb weaver in its retreat only if it can drive or lure the spider from the retreat. The wasp can only drive the spider from its retreat if it can find it, and if the retreat is not in a sheltered spot. It can probably only lure it out with relatively complicated behavior like that of Belanogaster junceus (?) which hovers next to the hub of the web and taps it with its antennae and perhaps its front legs to lure the spider to the hub (MacNulty 196I).

It is possible that wasp predation has been a selective force influencing web site selection, as the observations above indicate that $S$. caementarium might be less likely to encounter well-scattered webs in cool places.

Araenus cornutus appears to have two effective close range defenses against wasp attacks: a quick unobserved exit from its retreat, and 
cryptic coloration and posture when it lands below. Both of these tactics may help explain why some orb weavers such as Zygiella litterata (Kaston 1948) and Singa haemata (Nielson I93 I) build retreats with two open ends, and why some such as $A$. cornutus are crytically colored even though they are normally hidden during the day. The behavior of $A$. humilis and $S$. caementarium indicate that while there may be selective pressure on orb weavers to hide themselves, there is probably little or no pressure to hide their webs, at least from these species.

\section{REFERENCES}

Evans, H. E., and C. M. Yoshimoto

1962. The ecology and nesting behavior of the Pompilidae (Hymenoptera) of the northeastern United States. Misc. Publs ent. Soc. Am. 3: 67-119.

Gertsch, W. J.

1949. American Spiders. D. Van Nostrand Co., Inc., Princeton, New Jersey. pp. 1-285.

KAston, B. J.

1948. Spiders of Connecticut. Conn. State geol. and nat. Hist. Survey, Bull. 70 : 9-874.

MacNulty, B. J.

1961. Field observations on some West African Hymenoptera. Proc. S. Lond. ent. nat. Hist. Soc. 1961: 118-133.

МсCоoк, H. C.

1889. American Spiders and their Spinningwork. Vol. 1. Webs and Nests. Published by the author, Philadelphia.

Muma, M. H., and W. F. JefFers

1945. Studies of the spider prey of several mud-dauber wasps. Ann. ent. Soc. Am. 38 : 245-55.

Nielson, E.

1931. The Biology of Spiders. Vol. 1. Levin and Munksgaard, Copenhagen.

Peckham, G. W., and E. G. Peckham

1905. Wasps Social and Solitary. Houghton, Mifflin, and Co., Boston. RAU, P.

1935. The spider prey of the mud wasp Sceliphron caementarium SOYER, B. (Araneae, Hymen. : Sphegidae). Ent. News 46: 267-270.

1950. Notes sur les Sphegians et les Pompiles. IX. Les Pompiles des vieux murs. Bull mens. Soc. linn. Lyon. 19(8) : 181-186 

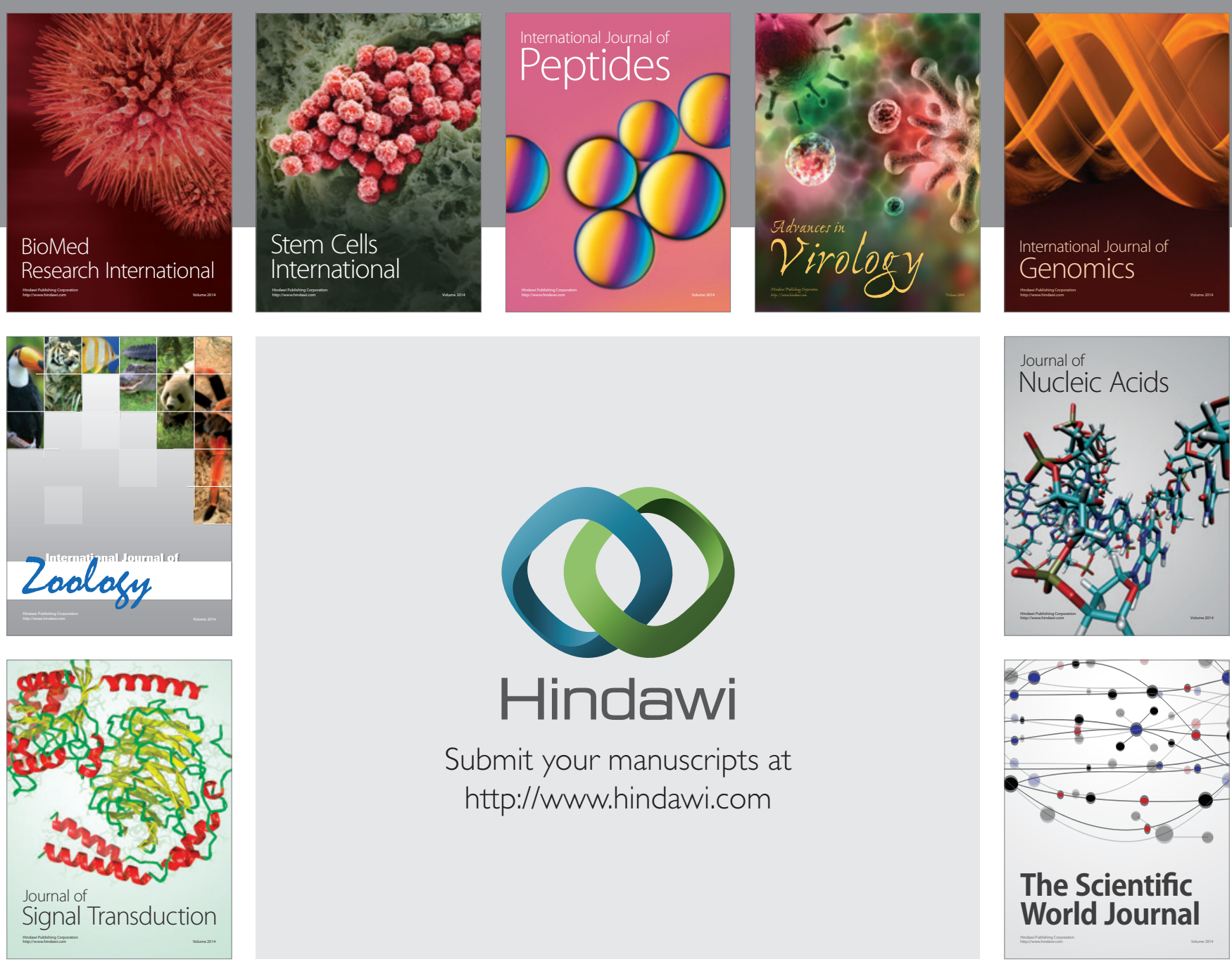

Submit your manuscripts at

http://www.hindawi.com
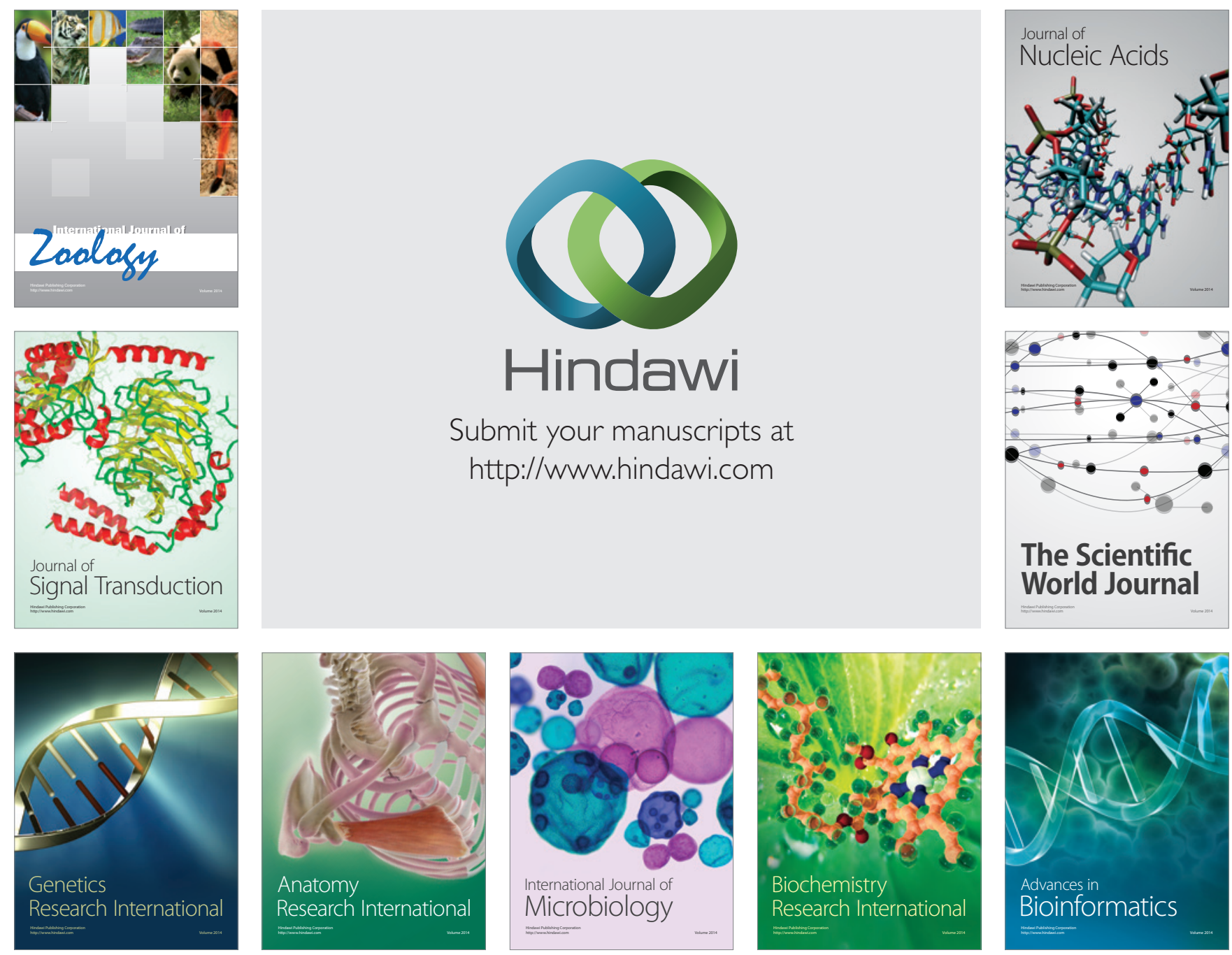

The Scientific World Journal
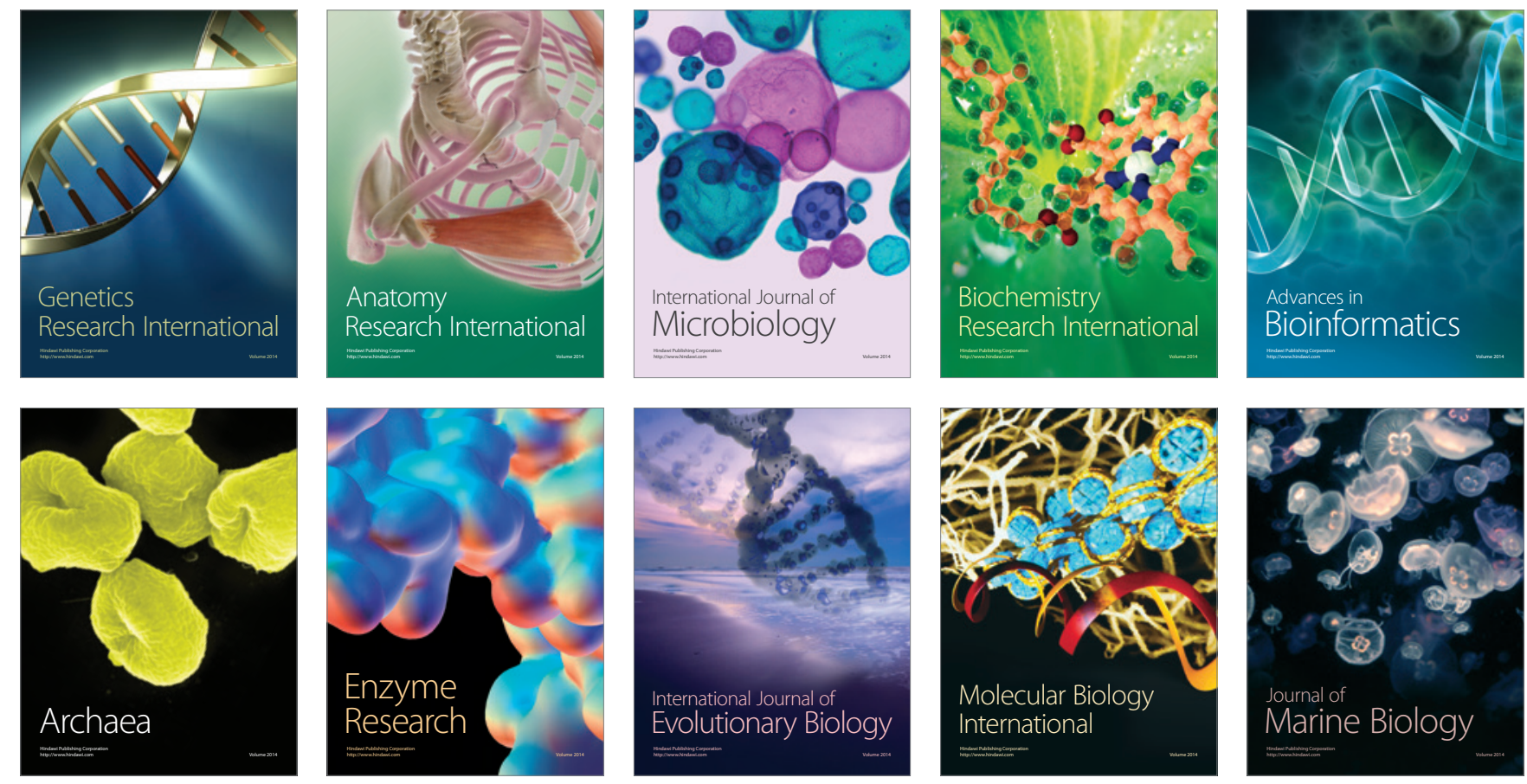